\section{pesquisa em administração}

\begin{abstract}
1. Introdução;
2. Industrializagão e burocratizaf̧ä; 3. Aspectos culturais da hierarquia brasileira: centralização, especialização e formalização;

4. Algumas hipóteses;

5. Metodologia;

6. Coleta de dados;

7. Variáveis e escalas;

8. Resultados - tendências convergẹntes: caracteristicas universais;

9. Tendências divergentes: caracteristicas nacionais; 10. Discussão e concluséo;

11. O uso da metodologia de Aston em pesquisas interculturais: algumas implicaf̧ōes metodológicas.
\end{abstract}

\section{Estrutura organizacional brasileira: aplicacão do modelo de Aston e implicações metodológicas}

Suzana Braga Rodrigues Do CMA/FACE/UFMG

Raquel C. Radamés de Sá

Da Universidade Federal de Uberlandia

\section{INTRODUÇÃO}

Os estudos sobre a estrutura organizacional têm suas raízes no conceito de Max Weber sobre a organizaçăo burocrática, que até o início dos anos 60 era entendido de maneira unidimensional, isto $E$, supunha-se que as organizaçð̃es burocráticas por definição englobariam todas as. características do tipo ideal. Nos meados da década, já vários estudos desafiaram essa noçăo com evidências de que organizaçoes diferem entre si em termos de várias dimensóes burocráticas. ${ }^{1}$ Dentre estes, 0 estudo de Aston foi um dos que mais influenciou idéias e pesquisas na teoria organizacional, não só pela introdução de uma visáo multidimensional da burocracia, mas por usar uma metodologia que tornou viável a comparação de organizaçóes com fins e produtos diferentes ${ }^{2}$ e, poteriormente, por possibilitar a comparação de organizaçóes através de diferentes culturas. ${ }^{3}$ As replicaçoes e extensóes que se seguiram ultrapassaram as fronteiras do país e posteriormente as da cultura anglo-saxônica com os trabalhos sobre estrutura de organizaçoes na India, ${ }^{4}$ Egito $^{5}$ e Jordânia. ${ }^{6}$

Esta proliferaçáo de estudos sobre estrutura organizacional utilizando a metodologia de Pugh e colaboradores trouxe para o âmbito da teoria organizacional a questão: as formas organizacionais acompanharam algum padrão específico, por exemplo, os modelos do mundo industrializado? Em relação a isto, dois pontos de vista se distinguem. Primeiro, há os que acreditam na lógica do industrialismo, no poder uniformizante das multinacionais e na força da tecnologia ${ }^{7}$ e há os que atribuem importância à cultura como fator responsável pelas particularidades das organizaçoes.

Os adeptos da lógica do industrialismo concordam que as sociedades em desenvolvimento tendem a assimilar estruturas e padrões das sociedades mais avançadas, independentemente de suas características culturais ou sistema político. Esta corrente supõe que a industrializaçáo traz desenvolvimento tecnológico, crescimento organizacional, diversificação e produção em grande escala e tais fatores terminam por exigir mais racionalidade na administração. Da mesma forma, a diversificação e a concorrência trazem a necessidade de economias de escala e sáo estas pressōes que tornam as organizaçoes do período pré-industrial mais vulneráveis, tornando a formação de alianças e o crescimento essenciais à sobrevivência.

Chandler ${ }^{8}$ expóe como a substituição das forças do mercado (invisible hand) pelas hierarquias profissionais (visible hand) foi essencial em termos da sobrevivência e expansão das grandes empresas, não só nos EUA, mas também na França, Inglaterra e Alemanha. Outros autores analisam a influência da industrializaçáo sob uma outra ótica. Clegg \& Dunkerley ${ }^{9}$ discutem os problemas comuns que afetam as organizaçoes em qualquer país capitalista como, por exemplo, os da estrutura do trabalho e conflitos entre empregados e empregadores. Preocupam-se ainda com as pressరes que organizaçoes públicas como hospitais e instituiçoes educacionais vêm sofrendo para adotar critérios capitalistas, principamente no que diz respeito a finanças e pessoal.

Estendendo este tipo de raciocínio ao nível da organização, Hickson \& McMillan $^{10}$ desenvolveram a idéia da culture-free hypothesis. Segundo estes autores, $a$ industrialização traz necessariamente o desenvolvimentecnológico, crescimento das organizaçoes e aumen to da interdependência organizacional, pela expansáo das forças de mercado.

Estes fatores têm um impacto direto na reformulação da estrutura da organizaçáo, exigindo uma administraçáo mais profissionalizada que resultaria numa nova opçáo, a substituição do controle pessoal por regras e procedimentos formalizados. Esta lógica contingencial visa uma teoria transnacional das organizaçoes passível de ser testada em diferentes sociedades, através do esquema conceitual e metodológico de Aston, que possibilita a verificaçáo das relaçoes entre contexto (tamanho e dependência) e estrutura (centralização, formalização e especialização).

As críticas dirigidas à teoria contingencial e à idéia da industrialização como força material homogeneizante sấo inúmeras. Primeiramente, existem aqueles que argu- 
mentam que o ajustamento da organizaço ao ambiente é permeado pela ação dos membros. Conseqüentemente, as decisర̃es sao tomadas de acordo com os significados, culturalmente determinados, que estes membros atribuem às exigências ambientais. ${ }^{1}$ Um outro tipo de restrição feita à teoria das organizaçóes em geral é a sua especificidade cultural. ${ }^{12}$ Alguns autores resumem bem o estado da arte, como por exemplo, Hickson e colaboradores, ${ }^{3}$ que se referem à teoria como "an American edifice fabricated on a foundation of West European Weberian thought". Entretanto, a multiplicação de estudos em sociedades diferentes pode ser tomada como uma reação a críticas desta natureza. Permanece ainda a dúvida se a pesquisa intercultural preocupada com o carater universalista das práticas administrativas tem conseguido captar os aspectos mais relevantes das organizaçoes nos parses pesquisados, ou se a superficialidade destes estudos tem impedido a sensibilidade a variaçðes culturais.

Os autores que apóiam a tradiçáo cultural săo os que mais se opõem à pretensão universalista da teoria organizacional. Este grupo de teóricos afirma que as características das organizaçðes e de seus membros variam com a sociedade e, portanto, comparaçōes interculturais sao possíveis somente em termos qualitativos. Crozier, ${ }^{14}$ por exemplo, é um dos que apóiam o ponto de vista culturalista. Segundo ele, as limitaçøes da teoria organizacional só podem ser superadas na medida em que as organizações e práticas administrativas sáo entendidas como "respostas culturais aos problemas encontrados por seres humanos para se alcançar fins coletivos". Segundo Child \& Tayeb, ${ }^{15}$ na tradição cultural há os que definem cultura em termos de um sistema de idéias e os que a conceituam como um sistema adaptativo. No primeiro caso, os autores atribuem importância a idéias, valores e atitudes que são compartilhados por membros da organização em determinadas sociedades.

Dentro desta perspectiva, Hofstede ${ }^{16}$ propoe uma definição de cultura em termos de um programa mental que cada indivíduo desenvolve através de socialização nas escolas e organizações. Sua pesquisa desenvolvida em subsidiárias de uma grande multinacional mostra as implicaçóes de fatores culturais para a formulação de políticas em multinacionais.

Os estudos que adotam o ponto de vista da cultura como sistema adaptativo dáo importância à tecnologia, à economia e às instituiçðes sociais como indicadores da adaptação cultural. Aqui, as organizaçōes são consideradas reflexos das características institucionais do país e valores dominantes. Deste modo, a divisão do trabalho, as exigências quanto à profissionalização nas organizações, expressam muito mais as peculiaridades sócio-culturais do que qualquer força universal.

Em relação ao conceito de cultura, há autores como Sorge $^{17}$ e Child ${ }^{18}$ que são favoráveis à síntese entre estes dois pontos de vista. Sorge ${ }^{19}$ propôe um conceito muito similar à teoria da ação de Silverman. Do seu ponto de vista, cultured organizations implica que as organizações são produtos da ação humana; cultured actors é um termo que sugere que as decisóes sto culturalmente determinadas e, porntanto, são irracionais.

Tanto a teoria contigencial quanto a tradição cultural requerem tratamento metodológico diferenciado. ${ }^{20}$ Por exemplo, os estudos que adotam o segundo paradigma são organizados dentro de um tratamento nomotético, enquanto os culturais requerem uma abordagem tipo ideogrática. $O$ enfoque ideográfico pressupóe que a relação entre a organização e o seu contexto sáo particulares de um determinado tempo e espaço; atribuem importância ao estudo intensivo de casos e à sensibilidade às origens históricas das características da organização. Nesta perspectiva, a pesquisa intercultural só tém sentido através da análise qualitativa e enfoque nas interligaçoes da organização com o contexto sócio-cultutal em que se insere. Em contraposiçáo a isto, os trabalhos nomotéticos dirigem a atenção para o universalista, isto é, para as características que transcendem espaço e tempo, e atribuem importância ao tratamento quantitativo. ${ }^{21}$ Portanto, a ênfase coṇsiste na estabilidade das relaçōes entre contexto e estrutura, por exemplo, e nos métodos quantitativos.

A idéia de examinar a estrutura das organizaçóes brasileiras dentro da perspectiva da convergência organizacional versus a idéia da divergência cultural nos pareceu bastante atrativa. $O$ uso de dois paradigmas parcial pertinente no caso do Brasil, dado o rápido desenvolvimento industrial nas duas últimas décadas e à pressáo decorrente para a modernização das organizaçoes. Isto, no entanto, demanda uma breve revisão do nosso processo de industrializaçáo, bem como uma análise de alguns traços relevantes da cultura brasileira.

\section{INDUSTRIALIZAÇÃO E BUROCRATIZAÇÃO}

Se examinarmos a nossa história industrial, podemos identificar alguns exemplos em que o desenvolvimen to trouxe consigo pressōes para que as organizaçóes se modernizassem no sentido de incorporar características do modelo weberiano. Em contraste com países como a Inglaterra, onde modelos modernos de administraçao surgiram gradualmente com a complexidade das organizaçơes e como conseqüência do próprio processo de industrialização, no Brasil a burocratização no sentido mencionado foi imposta por uma elite como parte do pacote industrial. Entretanto, não podemos afírmar que esta seja uma característica específica da industrialização no Brasil. 0 mesmo fenômeno foi observado em ouros países que tiveram desenvolvimento tardio. ${ }^{22}$

Com intuito didático, preferimos separar dois momentos principais no processo de desenvolvimento brasileiro em que poderíamos encontrar paralelamente tentativas de modernização administrativa. Na década de 30 , por exemplo, os eforços para dinamizar a economia através da criação de empresas estatais foram concomitantes a um esforço do governo para modernizar seu aparato administrativo. A criaçao do Dasp em 1938 visava a introduçáo de métodos de trabalho segundo os modelos de Weber, Taylor e Fayol. ${ }^{23}$

No segundo período de industrializaçăo do país, a associação entre industrialização e burocratização pode ser identificada de maneira mais clará. A partir da II Guerra Mundial, houve um esforço para se acelerar e generalizar a industrialização através da ação de uma elite interessada em difundir a ideologia capitalista, aliada a idéias da racionalidade weberiana e aos princípios clássicos de administraçáo. ${ }^{24}$ Este grupo, constituído de 
empresários de multinacionais, altos funcionários da administração pública, técnicos de empresas estatais e militares, conseguiu articular-se de forma a atuar em vários centros de poder simultaneamente como, por exemplo, através da participaçáo na direção de multinacinais, associaçð̃es de classe, cargos-chrve do governo e empresas de consultoria tecno-empresarial.

A influência da ideologia norte-americana se deu no Brasil indiretamente através da liderança deste país no bloco de multinacionais, através de escolas de administraçáo pública e de empresas e através dos centros de treinamento em administração sob a Ggide da American Management Association. Estas instituiçoes deveriam não só difundir o know-how administrativo dos países mais desenvolvidos, como também preparar quadros para a administração pública e privada. Paralelamente, os escritórios de consultoria tecno-empresarial, a maioria criada na década de 50, estavam preparados para prestar assistência técnica ao planejamento empresarial, bem como para conscientizar sobre a importância da administraçao eficiente. ${ }^{25}$

A introduçáo de modelos modernos de administração após a II Guerra Mundial deu-se nðoo somente no setor privado empresarial, mas também aconteceu no setor público, através de outros esforços reformistas na administração pública a partir da década de 50 e final da década de 60. As tentativas reformistas da década de $\mathbf{5 0}$ ainda apresentavam basicamente as mesmas preocupaçóes do momento da criaçáo do Dasp; por exemplo, havia ênfase na expansáo do sistema do mérito, treinamento de funcionários e planejamento. O Decreto-lei n! 200 , de 1967 , enfatizava a prática dos princípios clássicos da administração, dando prioridade ao planejamento, coordenaçáo, descentralizaça, delegaça de competência é controle. ${ }^{26}$

As conseqüências dos esforços de se acelerar o desenvolvimento industrial nos últimos 20 anos impressionam, à primeira vista, pela proliferaçáo de grandes organizaçōes, principalmente subsidiárias de multinacionais e as grandes empresas estatais. Por outro lado, ainda permanece a questao de se saber se realmente houve transferência de idéias quanto ds relaçós de trabalho ou funcionamento de organizaçóes. Quanto ao setor empresarial, Bresser Pereira ${ }^{27}$ conclui que as empresas nacionais ainda estão aquém das empresas estrangeiras em termos de estruturaçáo e democratização do capital. Quanto aos esforços reformistas da administraçáo pública, o ceticismo parece ser generalizado. ${ }^{28}$ Isso nos leva ao argumento da teoria culturalista, segundo a qual os membros da organização modificam os modelos importados de modo a preservar os valores e padróes de comportamento vigentes. Dentro desta perspectiva, também no Brasil poderiamos encontrar padróes de organizaça discrepantes do racionalismo capitalista previsto por Hickson \& MicMillan, ${ }^{29}$ mas coerentes com valores e relaçes interpessoais anteriores ao processo de industrializaçáo. Portanto, como tínhamos interesse em examinar a importância da cultura bem como do.processo industrial, procuramos identificar alguns fatores da cultura brasileira que poderiam influenciar as características estruturais, muito embora náo dispuséssemos de instrumentos para testar diretamente este tipo de influencia. Embora tives- semos consciência das inúmeras dimensóes culturais da sociedade brasileira, a nossa intençâo era limitar a análise apenas aquelas que pudessem ser associadas mais de perto às variáveis de estrutura.

\section{ASPECTOS CULTURAIS DA HIERARQUIA BRASILEIRA: CENTRALIZAÇÃO, ESPECIALIZAÇÃO E FORMALIZAÇÃO}

A maioria das replicaçoses e extensōes do estudo de Aston aborda principalmente três variáveis da estrutura organizacional: centralizaçá, especializaçao e formalizaçáo. Estas dimensoes burocráticas dizem respeito à divisao e controle do trabalho. Por exemplo, vários autores distinguem a organizaçáo burocrática moderna em termos dá presença de uma hierarquia bem definida de autoridade, divisto do trabalho fundamentada em epsecializaço funcional, regras e procedimentos formais, impessoalidade e seleçáo com base na competência. ${ }^{30}$

Brossard \& Maurice ${ }^{31}$ rejeitam este tipo de modelo burocrático com características universais e estruturado segundo determinadas contingências. Com base em um estudo empírico de organizaçoes francesas e alemas, os autores concluem que as diferenças estruturais podiam ser explicadas por fatores internos que eram peculiares também ao ambiente externo. Por exemplo, a divisáo interna do trabalho consistia numa extensáo dos sistemas educacionais nos dois países.

Fenômeno semelhante no contexto brasileiro foi apontado por Bertero..$^{32} \mathrm{O}$ autor mostra como algumas caracterísitcas do relacionamento interpessoal e da estrutura social se repetem dentro das organizaços. Um exemplo seria o caráter autoritário, herança da oligarquia agrária que permeia a sociedade brasileira. $\mathbf{O}$ autoritarismo se manifesta em qualquer situação onde há divisão de poder, seja na familia, nas relaçoes de amizade, nas relaçóes entre superior e subordinado. Nas organizaçóes, - autoritarismo se caracateriza por maior rigidez nas relaçóes de autoridade, contribuindo para o centralismo das decisões. Porém, não é apenas o autoritarismo que leva à centralização de decisoes. A própria estratificaçáo da sociedade em dois segmentos principais, marginal e central, rural e urbano, se repete no interior das organizaçóes, contribuindo para que as decisoes sejam mantidas no topo. O fato de que os individuos com status, educaçáo e renda estejam nos niveis mais altos, e os individuos com menos educação, menor renda e da zona rural estejam colocados nos niveis inferiores constrange a delegaçáo de decisoes a este nível, que se justifica através da falta de confiança na competência.

Nos tempos da oligarquia agrária, o chefe de família era considerado representante máximo da autoridade, respeitabilidade e coesto entre as pessoas. $O$ isolamento geografico entre os latifúndios contribuiu para o organizafaro das fazendas em sistemas auto-suficientes em termos econômicos e sociais, tornando os valores que fortaleciam a proteçáo aos membros e a unidade familiar essenciais a sobrevivência. ${ }^{3}$ Foi desta primeira unidade econômica que surgiram alguns valores e padrós de comportamento que sto observados nas relaços interpeseoais em geral, nos dias de hoje. 0 autoritarismo, 0 predomínio do particular sobre o público e principal- 
mente o compadrio foram estendidos à administração pública na medida em que a oligarquia se enfraqueceu como sistema econômico e quando as organizaçбes públicas passaram a ter importância como fonte de emprego. ${ }^{34}$ A idéia de proteção a familiares e amigos encontra sua mais clara expressão nestas organizaçóes, onde os cargos públicos-vêm sendo preenchidos por favoritismo. Da Cunha ${ }^{35}$ relata que, até 1949 , o número de pessoas que ingressaram nas burocracias públicas por favoritismo sobrepunha aos que foram admitidos por critérios universalistas. Na nossa sociedade atual, este ainda continua serido um dos instrumentos mais importantes de ascensão ao poder político.

A maneira como o pessoaiismo se encontra impregnado nas relaçōes interpessoais na sociedade é muito bem ilustrada por Da Matta. ${ }^{36}$ Segundo o autor, um dos dilemas que a industrialização e a vida urbana vêm impondo ao brasileiro é a distinção entre "pessoa" e "indivíduo". A familia é o lugar de expressáo máxima da "pessoa", enquanto o ambiente externo e o trabalho requerem o exercício do papel "indivíduo". Assim que atinge a maturidade e obtém um trabalho, 0 "individuo" se acha diante de um novo jogo, $o$ das regras universais e tratamento impessoal. Nas organizaçóes, a formalização traz impessoalidade no relacionamento e as regras devem ser aplicadas indiferentemente da pessoa. Com o passar do tempo, o tratamento impessoal termina por ceder aos laços de amizade, fazendo com que as relaçōes entre subordinado e superior assumam o caráter pessoal. Assim, sugere o autor, o pessoalismo enfraquece ơ poder de controle das leis burocráticas. $O$ tratamento impessoal é sempre rejeitado; quando os recursos da amizade não podem atuar diante da eminência do golpe fatal da aplicação da lei ou reguiamento, há sempre outras estratégias disponiveis, a da revelação ostensiva da própria identidade ou através do "jeitinho". ${ }^{37}$

Até que ponto o "jeitinho" e a generosidade da burocracia para com "pessoas" é causa ou consequeência do caráter formalístico das regras universais no Brasil, é uma pergunta para a qual náo existe resposta pronta, nem è esta uma questáo que interessa de perto a este trabaiho. Porém, sabemos que o mecanismo do formalismo opera de tal forma que a não-obediência a leis leva à criação ostensiva de novas regras para reforçar as primeiras. Logo, se a burocracia introduz critérios estranhos à divisão do trabalho e o tipo de relaçōes interpessoais, alicerçado na amizade e intimidade, termina também por enfraquecer o poder de controle de regulamentos gerais, torna-se necessário o acúmulo de documentos, de modo a se dar a impressão que as decisóes são tomadas de acordo com critérios universalistas.

A presença destas formas de expressão cultural nas organizaçбes vem sendo apontada por diversos trabalhos, principalmente na administração pública. Embora não saibamos a extensão da predominância destas características em empresas privadas, o nosso ponto de vista é de que elas refletem padróes de comportamento cristalizados ao longo do tempo, permeando os diversos aspectos da vida social. Por outro lado, não podemos desconsiderar o papel relevante do empresariado brasileiro na difusăo de modelos e técnicas administrativas durante o processo de industrialização, nem ignorar que as orgznizaçóes de fins lucrativos não têm condiçơes de sobreviver sem dar primazia à racionalidade econômica. Não obstante, a impressáo que se tem é a de que, apesar da influência do processo de industrialização, ainda permanecem muitas contradiçōes do sistema anterior. Por isso, as hipóteses que serviram de orientação para o trabalho empirico levam em conta as contingências do desenvolvimento industrial de um lado e consideram o impacto da cultura, de outro.

\section{ALGUMAS HIPOTESES}

A nossa primeira hipótese tem por base a teoria da contingência, em particular, the culture-free hypothesis. Conforme mencionado, a teoria prediz que grandes organizaçóes se tornam mais complexas através da divisão do trabalho e maior especializaçáo de atividades. Isto traz problemas de coordenação que são resolvidos através de delegação de autoridade juntamente com maior controle formal. Ainda seguindo esta linha de raciocínio, partimos da suposição de que, com o desen volvimento da economia, as ligaçoes contratuais das organizações tendem a se expandir. Esta ampliação da interdependência com clientes e fomecedores implicaria a centralizaçáo de decisǿes e necessidades de consulta à matriz.

Estudos em diversos ambientes econômicos e políti$\cos$, tanto em sociedades industrializadas quanto em de. senvolvimento, capitalista ou socialista, indicaram que estas relaçðes entre contex to e estrutura se mantiveram estáveiss ${ }^{38}$ A nossa primeira expectativa era a de que os resultados para o Brasil deveriam seguir as tendências encontradas nestes estudos, como indicado na tabela 1 .

Tabela 1

Correlações esperadas entre contexto e estrutura

\begin{tabular}{lccc}
\hline & Formalização & Especialização & Centralizaçáo \\
\hline Tamanho & + & + & - \\
Dependência & + & & + \\
& (Freqüentemente) & & \\
\hline
\end{tabular}

Não obstante, considerando o centralismo das decisões e a competiçáo dos critérios pessoais de ingressos com a qualificação profissional e 0 apego a papéis nas organizações brasileiras, partimos do pressuposto de que tais fatores iriam refletir-se através de níveis de estrutura. Logo, compatando as organizaçðes da nossa amostra com as de países industrializados, esperávamos encontrar para as brasileiras graus mais elevados de centralização e formalização e mais baixos de especialização.

\section{METODOLOGIA}

Ao definir a amostra e a metodologia, procuramos manter-nos tanto quanto possível dentro dos parâmetros definidos inicialmente por Pugh \& Hickson ${ }^{39}$ e pelas replicaçós subseqüentes. Como mencionado no início 
Tabela 2

Características da amostra nos estudos interculturais que utilizam a metodologia de Aston

\begin{tabular}{|c|c|c|c|c|c|}
\hline \multirow{2}{*}{ Estudos } & \multirow{2}{*}{\multicolumn{2}{|c|}{$\begin{array}{l}\text { Número de } \\
\text { organizações }\end{array}$}} & \multicolumn{3}{|c|}{$\begin{array}{l}\text { Tamanho de organizações } \\
\text { (Número de empregados) }\end{array}$} \\
\hline & & & Média & $\begin{array}{l}\text { Desvio- } \\
\text { padrão }\end{array}$ & $\begin{array}{l}\text { Distri- } \\
\text { buiçẫo }\end{array}$ \\
\hline \multirow[t]{3}{*}{ Hickson et alii } & EUA & (21) & 5.150 & 8.400 & $250-25.000$ \\
\hline & Canadá & (24) & 500 & 350 & $200-1.200$ \\
\hline & Grã-Bret. & (25) & 2.650 & 4.000 & $250-18.200$ \\
\hline Pugh et alii & Grã-Bret. & (31) & 3.411 & 5.644 & $284-25.052$ \\
\hline Child & Grā-Bret. & (40) & 1.505 & 2.054 & $108-7.619$ \\
\hline \multirow[t]{3}{*}{ McMillan et alii } & Grąa-Bret. & (11) & 529 & 487 & $80-1.600$ \\
\hline & Suécia & (11) & 658 & 603 & $126-1.657$ \\
\hline & Japão & (11) & 509 & 458 & $110-1.672$ \\
\hline Azumi & Japão & (50) & 946 & 985 & $100-4.500$ \\
\hline Kieser & Alemanha & (51) & 895 & NA & $85-3.324$ \\
\hline Kuc et alii & Polônia & (11) & 496,1 & NA & $105-1.550$ \\
\hline Ayoubi & Jordânia & (34) & 234 & 354 & $30-1.511$ \\
\hline Badran \& Hinnings & Egito & (31) & 1.375 & ; NA & $305-4.700$ \\
\hline Rodrigues \& Sá & Brasil & (24) & 1.573 & 5.189 & $200-18.000$ \\
\hline
\end{tabular}

deste artigo, um dos nossos propósitos era examinar como as organizaçóes nacionais têm incorporado padrôes de estruturação de atividades predominantes em sociedades modernas. Tomando como base o estudo de McMillan e colaboradores, ${ }^{40}$ a amostra neste estudo consiste de 24 organizações industriais e não-industriais, sete das quais são subsidiárias de multinacionais, 14 são empresas nacionais privadas e três são organizaçōes públicas. As subsidiárias nacionais são de diferentes origens: três pertencem a diferentes grupos norte-americanos, duas têm matrizes italianas,-uma pertence a um grupo francês e uma a um grupo alemão.

As organizações da amostra foram selecionadas de uma listagem de organizaçóes situadas ao redor da área metropolitana de Belo Horizonte. Tentamos manter a variação do tamanho das organizaçóes dentro dos limites do estudo original ou den tro das variaçóes da amostra de McMillan ou de Kuc e colaboradores ${ }^{41}$ cujos estudos envolviam comparaçốes através de várias sociedades industrializadas. Infelizmente não nos foi possível manter a mostra rigidamente dentro dos limites das pesquisas anteriores, uma vez que não conseguimos obter uma lista atualizada das empresas da regiáo. Os dados publicados pelo Serpro eram de 1978 e neste caso a lista não ajudou muito, devido a alteraçóes recentes nos níveis de emprego provocadas pelas profundas mudanças econômicas, nos últimos dois anos. No que se refere ao tamanho, as organizaçбes na presente pesquisa variaram de 200 empregados (um departamento público de engenharia civil), a 18 mil empregados (uma graride fábrica de carros). A tabela 2 mostra a distribuiç̧ăo, em tamanho, das organizaçẽos brasileiras quando comparadas a estudos já conduzidos em outros parses.

Embora não tenhamos obtido equivalência em relação à variável tamanho, considerando-se especialmente as replicaçбes anteriores, conseguimos incluir organizaçoes com diferentes produtos e atividades e com variado grau de dependência da matriz (ver tabela 3 ). A classificação das organizaçōes em termos de status sofreu adaptação, uma vez que no Brasil usamos outro sistema de classificação.

Tabela 3

Tamanho, principais produtos e status das unidades organizacionais

\begin{tabular}{|c|c|c|}
\hline $\begin{array}{l}\text { Tamanho } \\
\text { No de } \\
\text { empregados }\end{array}$ & $\begin{array}{l}\text { Principais linhas } \\
\text { de produtos }\end{array}$ & $\begin{array}{l}\text { Status da } \\
\text { organização }\end{array}$ \\
\hline 200 & $\begin{array}{l}\text { Departamento público de } \\
\text { engenharia civil }\end{array}$ & Unidade regional \\
\hline 206 & Confecçōes & Unidade principal \\
\hline 210 & Escola superior privada & Unidade principal \\
\hline 223 & Revendedor de veículos & Unidade principal \\
\hline 223 & Borracha & Unidade principal \\
\hline 270 & Engenharia civil & Unidade principal \\
\hline 361 & $\begin{array}{l}\text { Departamento público de } \\
\text { ciência e tecnologia }\end{array}$ & Unidade regional \\
\hline 400 & Produtos elétricos & Subsdiária \\
\hline 400 & Telhas & Subsidiária \\
\hline 400 & Engenharia civil & Unidade principal \\
\hline 430 & Plásticos & Subsidiária \\
\hline 500 & Cerâmica & Unidade principal \\
\hline 650 & Escola pública de treinamento & Unidade regional \\
\hline 845 & Alimentos & Unidade principal \\
\hline 869 & Jornais & Subsidiária (divisão) \\
\hline 970 & Calçados & Unidade principal \\
\hline 990 & Indústria mecânica & Subsidiária \\
\hline 1.200 & Cimento & Unidade principal \\
\hline 1.500 & Companhias de ônibus & Unidade principal \\
\hline 2.000 & Metalurgia & Subsidiária \\
\hline 2.000 & Siderurgia & Unidade principal \\
\hline 2.200 & Têxtil. & Unidade principal \\
\hline 2.705 & Indústria mécânica & Subsidiária \\
\hline 18.000 & Veículos & Subsidiária \\
\hline
\end{tabular}

\section{COLETA DE DADOS}

Os dados foram coletados, neste conjunto de organizaçōes, através de entrevistas estruturadas com diretores $e$, quando eles náo dispunham de informaçoses relevantes, com os chefes de departamento e outros executivos de alto escaláo.

Antes de enviarmos uma carta introdutória q̨o diretor ou presidente, se fosse o caso, fizemos uma experiência-piloto para testar a relevância das questóes no contexto brasileiro. Especialistas em pesquisas interculturais afirmam que os instrumentos para este tipo de pesquisa requerem equivalência intẹcultural e entre línguas. Isto não quer dizer que seja necessário haver uma correspondência lingüística exata; o que se exige basicamente é a equivalência conceitual. ${ }^{42}$ No processo de elaboração do instrumento de pesquisa, foi feita uma comparaçáo rigorosa com as escalas originais de Aston. Após o estudo-piloto, fizemos uma revișo da traduçáo, tomando o cuidado de manter a essência conceitual dos itens originais, mas sem perder 0 quadro de referência cultural dos informantes. Alguns itens do questionário tiveram de ser excluídos devido à falta de correspondência com a realidade das organizaçóes brasileiras. Os detalhes sobre as, 
modificações que se fizeram necessárias podem ser encontrados nos anexos. Um questionário específico teve de ser elaborado para as organizaçōes năo-industriais, tomando-se o cuidado para manter a equivalência com o correspondente para as organizações industriais. ${ }^{43}$

\section{VARIĀVEIS E ESCALAS}

As escalas que compuseram o questionário foram as mesmas desenvolvidas pelo grupo de Aston, mas incluímos no estudo apenas aquelas variáveis que foram examinadas mais freqüentemente pelos estudos interculturais. Das variáveis de contexto, incluímos apenas tamanho e dependência. Na pesquisa de Pugh \& Hickson ${ }^{44}$ o tamanho é medido em termos de número de empregados, mas para efeito de análise de dados utilizamos igualmente neste estudo o logaritmo do número de empregados como expressão de tamanho. Definimos dependência em termos da extensáo na qual uma organização mantém ligaçôes com seu próprio grupo ou outros grupos externos (fornecedores e consumidores), sendo que na presente pesquisa usamos as medidas desta variável com algumas modificaçoes. Em vez de usarmos a escala total, um índice de dependência foi computado para cada organização com base em apenas algumas escalas, a saber: escala no 12-12, escala no 12-11, escala n? 18-03, escala no 18-05, escala n? 18-08, escala n? 18-19, escala n? 18-10 (ver anexo 1).

Tínhamos interesse em três variáveis estruturais: formalização, especialização e centralização. Por formalização entendemos a extensáo na qual procedimentos, instruçōes, regras e comunicações são escritos. Neste estudo, uma medida total de formalizaçáo foi computada usando as escalas de Aston nọs 53-01, 53-02 e 50-03 (ver anexo 3). Desta escala, usamos apenas 39 itens; dois itens foram eliminados devido à falta de relevância $\mathrm{e}$ um outro foi adicionado por sua importância no contexto brasileiro. No estudo de Aston, especializaçáo funcional reflete o grau no qual as atividades em uma organização são divididas em funçбes mutuamente exclusivas. A escala usada consiste de 16 itens, como apresentados no anexo 3. Computamos um quando a organização dispunha de um especialista para a atividade em questão e zero no caso de não existir especialista. Compreendemos por centralização o nivel hierárquico no qual as decisoes săo autorizadas, mesmo se mais tarde elas sáo homologadas em um nível superior. No trabalho usamos a escala de Pugh \& Hickson ${ }^{45}$ n? 54-00, no anexo 3 .

\section{RESULTADOS - TENDENCIAS CONVERGENTES : CARACTERISTICAS UNIVERSAIS}

Sugeriu-se anteriormente que a maneira mais racional de se administrar a complexidade é através da divisło em unidades especializadas e padronização de procedimentos. Vejamos como isto se aplica no caso da nossa amostra. Pelos resultados apresentados na tabela 4 , as grandes organizaçбes têm procedimentos mais formalizados e parecem ser realmente mais diferenciadas em departamentos e número de especialistas. Não obstante, săo mais
Tabela 4

Correlações entre variáveis contextuais e estruturais para a amostra brasileira $(n=24)$

(Correlação de Pearson)

\begin{tabular}{|c|c|c|c|}
\hline \multirow{2}{*}{ Contexto } & \multicolumn{3}{|c|}{ Estrutura } \\
\hline & Formalizaçăo & Especialização & Centralização \\
\hline \multicolumn{4}{|l|}{ Tamanho } \\
\hline da organização ${ }^{1}$ & $0,40^{*}$ & $0,50 * *$ & 0,15 \\
\hline \multicolumn{4}{|l|}{$\begin{array}{l}\text { Depend ência } \\
\text { da organização }\end{array}$} \\
\hline com outras & $0,34^{*}$ & 0,53 ** & $-0,07$ \\
\hline
\end{tabular}

centralizadas, ao contrário do que os resultados gerais das pesquisas em outras naçōes indicavam (ver tabela 1). Em relação à dependência interna e externa, nossos resultados diferem das previsóes de Hickson \& McMil$\operatorname{lan}^{46}$, principalmente no que diz respeito à centralização. A maior incerteza decorrente da expansão da dependência com relação a clientes e fornecedores não conduz à centralização de decisðes na cúpula administrativa, como se pensava. Porém, as correlaçס̃es com as outras variáveis estruturais sugerem que as organizaçóes com mais ligaçōes contratuais são também as que têm mais especialistas e procedimentos formais.

Retornando ao argumento sobre tamanho e estrutura, havíamos partido do pressuposto de que, à medida que as organizaçбes crescem, elas tendem a mudar de um estilo pessoal de autoridade para um estilo mais participativo, ao mesmo tempo em que se criam regras e procedimentos escritos para controle de desempenho. Este tipo de mecanismo foi observado em organizaçóes de diversos países, independente da natureza do produto ou serviço, mas no nosso caso observamos que os três aspectos não combinavam da maneira prevista. Os resultados na tabela 5 sugerem que centralizaçáo é uma variav́el que não depende da presença de profissionais na organização nem do uso de meios alternativos de controle administrativo. Entretanto, a correlaçáo entre formalização e especialização é de 0,64 com um nível de confiança de 0,01 . Isto sugere que onde há mais diferenciação $e$ especialistas existem mais documentos para definir regras gerais e para controle de desempenho.

Tabela 5

Intercorrelações entre variáveis estruturais (Correlação de Pearson)

\begin{tabular}{lccc}
\hline & \multicolumn{3}{c}{ Amostra total $(n=24)$} \\
\cline { 2 - 4 } & Formalização & Especialização & Centralização \\
\hline Formalização & 1,00 & $0,64^{*}$ & 0,20 \\
Especialização & & 1,00 & 0,10 \\
Centralização & & & 1,00 \\
\hline
\end{tabular}

"p $<0,01$. 
Tabela $6^{1}$

Correlações entre variáveis contextuais e estruturais amostras para Brasil, Polônia, Japão, Suécia e Grã-Bretanha (Correlaçáo de Pearson)

\begin{tabular}{|c|c|c|c|}
\hline $\begin{array}{c}\text { Polônia } \\
(n=11)\end{array}$ & $\begin{array}{c}\text { Japão } \\
(n=11)\end{array}$ & $\begin{array}{l}\text { Suécia } \\
(\mp=11)\end{array}$ & $\begin{array}{l}\text { Grã-Bretanh: } \\
\quad(n=11)\end{array}$ \\
\hline \multirow{2}{*}{ Contexto } & \multicolumn{3}{|c|}{ Estrutura } \\
\hline & $\begin{array}{l}\text { Forma- } \\
\text { lização }\end{array}$ & $\begin{array}{l}\text { Especia- } \\
\text { lização }\end{array}$ & $\begin{array}{l}\text { Centra } \\
\text { lizaçăo }\end{array}$ \\
\hline \multicolumn{4}{|c|}{ Tamanho da organizaçđo ${ }^{2}$} \\
\hline Brasil & 0,54 & 0,70 & 0,18 \\
\hline Polônia & 0,26 & 0,67 & $-0,35$ \\
\hline Japāo & 0,69 & 0,21 & 0,04 \\
\hline Suécia & 0,68 & 0,26 & 0,22 \\
\hline Grã-Bretanha & 0,36 & 0,91 & $-0,54$ \\
\hline \multicolumn{4}{|l|}{$\begin{array}{l}\text { Dependência de outras } \\
\text { organizaçóes }\end{array}$} \\
\hline Brasil & 0,66 & 0,58 & $-0,33$ \\
\hline Polônia & 0,37 & 0,12 & 0,68 \\
\hline Japão & 0,55 & 0,18 & 0,41 \\
\hline Suécia & 0,43 & $-0,06$ & 0,73 \\
\hline Grã-Bretanha & $-0,04$ & $-0,38$ & $-0,10$ \\
\hline
\end{tabular}

1 Tabela adaptada de Kuc et alii (1981, p. 85).

2 Logaritmo do número de empregados.

Vejamos como os nossos resultados se comparam aos obtidos em pesquisas realizadas no Japão, Suécia, Polônia e Inglaterra. Na tabela 6 , os dados sobre os outros paises foram obtidos por Kuc e colaboradores ${ }^{47} \mathrm{e}$, para comparar nossos dados com os deles, tivemos que reduzir nossa amostra para 11 organizaçбes, eliminando aquelas sem finalidade industrial. Observa-se' que em todas as naçбes as grandes organizaçбes usam procedimentos mais formalizados e têm funçóes mais especializadas. Pode-se afirmar que, no geral, os dados brasileiros acompanham os resultados para os outros países, exceto no que diz respeito às relaçues entre contexto $\mathrm{e}$ centralizaçáo. Apesar de as sucessivas replicaçós na Inglaterra terem indicado a existência de correlaçáo nega tiva entre tamanho e centralização, nota-se no Brasil e na Suécia a existência de correlaçáo positiva, embora pequena, entre tamanho e centralização. No caso da Suécia, afirmam Kuc e colaboradores, ${ }^{48}$ os resultados não causam muita surpresa devi- do ao sistema de negociaçáo coletiva e de engenharia do trabalho que tendem a manter certas decisoes a nível de cúpula. No nosso caso, é possível que a composiçăo da amostra tenha influenciado a correlaçáo de 0,18 entre tamanho e centralizaçáo, uma vez que a proporção maior das organizaçoeš analisadas era composta por unidades principais. Neste caso, a maioria das decisóes é tomada internamente, ao nível da organizaça. A correlação de $-0,33$ entre dependência e centralizaçáo pode ser atribuída aos mesmos fatores.

As diferenças e similaridades entre as organizaçoes de cada país se tornam mais evidentes através da comparação dos níveis de estruturação. A tabela 7 mostra como as organizaçбes nestes cinco países se comparam nas três variáveis de estrutura.

Ả primeira vista, não existem diferenças muito grandes entre os resultados para o Brasil e os demais países, embora os brasileiros estejam mais próximos dos resulta. dos da Polônia, especialmente no que diz respeito à espezializaçáo e formalização. Como naquele país, as organizaçós no Brasil usam mais documentos e têm mais especialistas. No que diz respeito à formalização, o número mínimo de documentos usados pelas organizaçбes foi de 19. com uma média de 30,2 - a mais alta em comparação com outros paises. De acordo com as pesquisas interculturais que usam o mesmo esquema metodológico, apenas as organizaçóes da India ultrapassaram este total, com uma média de $34,3{ }^{49}$ As nossas organizaçóes apresentam também um nível alto de especializaçáo em comparaçáo com Japáo, Suécia e Inglaterra. $\mathrm{Na}$ amostra bra. sileira, o menor nûmero de especialismos encontrado por organização foi seis, enquanto no Japáo e na Inglaterra existem funçóes que não estáo sob a responsabilidade exclusiva de um especialista. A diferenciaçáo e especialização funcional nos surpreendem, considerando-se as suposiçбes que fizemos previamente e, mais ainda, a média de centralização da amostra brasileira, que é a mais baixa comparando-se com os resultados dos demais países. Por outro lado, devemos chamar a atençăo outra vez para as características específicas da nossa amostra, uma vez que podem interferir com as medidas agregadas de centralização. Até aí, os resultados sugerem que as organizaçбes no Brasil não apresentam diferenças estruturais importantes quando comparadas d̀s de países mais industrializados, o que nos leva a acreditar que de fato existe alguma estabilidade nas relaçoes entre contexto e

Tabela $7^{1}$

Comparação dos níveis estruturais em organizaçбes de diferentes países: dados sobre formalizaçăo, especialização e centralização

\begin{tabular}{|c|c|c|c|c|c|c|c|c|c|}
\hline & \multicolumn{3}{|c|}{.Formalização } & \multicolumn{3}{|c|}{ Especializaçào } & \multicolumn{3}{|c|}{ Centralização } \\
\hline & $\overline{\mathbf{x}}$ & DP & Variaçāo & $\bar{x}$ & DP & Variacto & $\overline{\mathbf{X}}$ & DP & Variação \\
\hline Brasil $(n=11)$ & 30,2 & 6,9 & $19-39$ & 12,4 & 30 & $6-16$ & 114,0 & 13,1 & 89-135 \\
\hline Polônia $(n=11)$ & 29,6 & 8,6 & $25-41$ & 12,8 & 2,3 & $10-14$ & 172,6 & 16,4 & $139-180$ \\
\hline Japão $(n=11)$ & 28,6 & 9,5 & $10-41$ & 8,2 & 3,0 & $0-13$ & 120,0 & 25,5 & $66-162$ \\
\hline Suécia $(n=11)$ & 22,6 & 11,0 & $13-37$ & 8,3 & 2,6 & $6-15$ & 125,4 & 9,5 & $111-142$ \\
\hline Grã-Bretanha $(n=11)$ & 27,4 & 7,3 & $14-37$ & 7,3 & 3,3 & $0-11$ & 119,9 & 12,5 & $104-141$ \\
\hline
\end{tabular}

1 Adaptação da tabela de Kuc et alii (1981, p. 88). 
Tabela $8^{1}$

Tipos de decisão e hierarquia

\begin{tabular}{|c|c|c|c|c|c|}
\hline \multirow[t]{2}{*}{ Decisōes } & \multirow{2}{*}{$\begin{array}{c}\text { Organizaçōes } \\
\text { britânicas }(n=71) \\
\text { Média }\end{array}$} & \multirow{2}{*}{$\begin{array}{l}\text { Organizaçōes } \\
\text { alemãs }(n=51) \\
\text { Média }\end{array}$} & \multicolumn{3}{|c|}{$\begin{array}{l}\text { Organizaçōes brasileiras } \\
\qquad(n=24) \\
\text { Média de centralização }\end{array}$} \\
\hline & & & $\begin{array}{l}\text { Amostra } \\
\text { total } \\
(n=24)\end{array}$ & $\begin{array}{l}\text { Propriedade } \\
\text { estrangeira } \\
(n=7)\end{array}$ & $\begin{array}{l}\text { Propriedade } \\
\text { nacional } \\
(n=17)\end{array}$ \\
\hline \multicolumn{6}{|l|}{ Decisōes estratégicas } \\
\hline $\begin{array}{l}\text { 1. Sobre o tipo de mercado } \\
2 \text {. Sobre novo produto ou ser- }\end{array}$ & 3,65 & 3,54 & 5,52 & 3,71 & 3,44 \\
\hline viço & 4,27 & 3,79 & 3,87 & 4,43 & 3,62 \\
\hline $\begin{array}{l}\text { 3. Sobre preço do produto } \\
\text { 4. Despesas com itens não-or- }\end{array}$ & 3,32 & 3,35 & 3,63 & 3,57 & 3,65 \\
\hline $\begin{array}{l}\text { çamentários de capital } \\
\text { Decisóes administrativas } \\
\text { 5. Criar um novo departamen- }\end{array}$ & 3,83 & 3,79 & 4,05 & 4,16 & 4,00 \\
\hline to & 4,09 & 3,96 & 3,95 & 4,14 & 3,64 \\
\hline 6. Alterar responsabilidade & 3,42 & 3,02 & 3,58 & 3,71 & 3,53 \\
\hline $\begin{array}{l}\text { 7. Criar um novo cargo } \\
\text { Decisóes de marketing }\end{array}$ & 3,62 & 3,90 & 3,70 & 3,86 & 3,62 \\
\hline $\begin{array}{l}\text { 8. Sobre prioridade de pedidos } \\
\text { Decisóes de produção }\end{array}$ & 1,77 & 2,62 & 3,14 & 2,83 & 3,26 \\
\hline $\begin{array}{l}\text { 9. Métodos de trabalho a serem } \\
\text { usados } \\
\text { 10. Horas extras a serem traba- }\end{array}$ & 1,37 & 2,64 & 2,91 & 2,57 & 3,06 \\
\hline $\begin{array}{l}\text { lhadas } \\
\text { 11. Operaçôes onde serão apli- }\end{array}$ & 1,58 & 2,46 & 3,29 & 3,40 & 3,25 \\
\hline $\begin{array}{l}\text { cados estudos de trabalho } \\
\text { Decisóes de compra }\end{array}$ & 2,29 & 3,10 & 3,20 & 2,71 & 3,46 \\
\hline $\begin{array}{l}\text { 12. Tipo/marca de novo equipa- } \\
\text { mento }\end{array}$ & 2,34 & 3,31 & 3,69 & 3,50 & 3.12 \\
\hline $\begin{array}{l}\text { 13. Fornecedores de materiais } \\
\text { Decisöes de pessoal }\end{array}$ & 1,64 & 2,62 & 2,95 & 2,80 & $\begin{array}{l}3,12 \\
3,0\end{array}$ \\
\hline 14. Seleção de trabaihadores & 1,66 & 2,44 & 2,95 & 3,00 & 2,93 \\
\hline 15. Promoções de trabalhadores & 2,63 & 2,82 & 3,08 & 2,86 & 3,19 \\
\hline 16. Seleção de supervisores & 2,82 & 3,27 & 3,24 & 3,14 & 3,30 \\
\hline 17. Promoção de supervisores & 3,35 & 3,54 & 3,27 & 3,14 & 3,30 \\
\hline 18. Salários de supervisores & 3,39 & 3,64 & 3,52 & 3,50 & 3,53 \\
\hline 19. Demissão de supervisores & 3,20 & 3,42 & 3,26 & 2,86 & 3,44 \\
\hline 20. Demissão de operários & 2,14 & 2,52 & 2,79 & 2,57 & 2,88 \\
\hline
\end{tabular}

estrutura, em diferentes sociedades. Se é verdade que o processo industrial é um fator de homogeneizaçđo de estruturas sociais, poderiamos, portanto, interpretar $o$ alto grau de especialização e formalização nas organizaçóes brasileiras como resultante do desenvolvimento tardio.

Segundo alguns autores, os países que iniciaram mais recentemente o processo de desenvolvimento tendem a assimilar modelos modernos em grandes saltos. A importância de tecnologia termina por queimar etapas, o que leva certas empresas a passarem de uma vez de um sistema manual de produção à automatização completa. Kuc e colaboradores, ${ }^{50}$ por exemplo, atribuem o grande número de especialistas e 0 alto indice de formalização nas organizaçōes polonesas à absorção rápida de tecnologia avançada e modelos administrativos modernos.

Ao contrário, poderíamos atribuir o alto índice de formalização não aos efeitos uniformizantes do desenvolvimento industrial, mas à tradição de apego aos papéis e documentos, observada nas instituiçoes brasileiras de modo geral. De maneira semelhante, a baixa correlação entre centralização e as outras variáveis estruturais poderia retratar a pouca participação com que se revestem os nossos sistemas decisorios, acima e a despeito das exigências da situação. Estas reflexбes nos trazem de volta à questão da cultura e mostram a necessidade de se examinarem os dados com mais detalhes ate o momento apresentados de forma agregada.

\section{TENDENCIAS DIVERGENTES: CARACTERISTICAS NACIONAIS}

No item anterior, chegamos à conclusto de que, apesar de haver evidências em favor da culture-free hypothesis, alguns dados davam margem para interpretaçós alternativas. No que concerne à centralização, os resultados nos surpreenderam não só pelo baixo índice de correlação com as variáveis de contexto, mas também com as outras duas dimensóes estruturais. Isto nos leva a questionar se 
as organizaçбos brasileiras tenderiam a reter as decisóes na cúpula administrativa, independente de qualquer demanda racional no sentido "thompsoniano". Achamos primeiramente que estes resultados poderiam ser atribuídos à composição da amostra, como já foi mencionado, mas examinando o nivel hierárquico em que as decisoes mais importantes e as de rotina sáo tomadas, obtivemos outras informaçס̄es que podem ser acrescentadas à explicação. De acordo com o procedimento de Child \& Kieser, ${ }^{51}$ agrupamos as diversas decisóes da escala n $\$$ 54-00 (ver anexo 4), segundo a sua importância e áreas funcionais a que se referiam. A tabela 8 mostra os níveis hierárquicos onde as decisóes sáo autorizadas. De acordo com a pontuação estabelecida no anexo 4 , as decisóes com o escore 5 sao as mais centralizadas, enquanto as decisóes mais próximas de 1 são tomadas no nível operacional. Separamos as organizaçoes nacionais das multinacionais porque achávamos que as últimas poderiam estar determinando as tendências dos dados agregados.

Tomando primeiramente os níveis de centralizaçto em organizaçб́es de propriedade nacional versus estrangeira, chamamos a atenção para o fato de que nas subsidiárias de multinacionais algumas decisôes são tomadas ao nível da diretoria da unidade ou nos níveis superiores, tais como aquelas que se referem a novos produtos, despesas com itens de capital nđo-orçamentários e criação de um novo departamento. Nestas organizaçóes, vários tipos de decisões sáo delegados aos chefes de área ou setor, como as que se referem aos métodos de trabalho, aquisição de material de rotina e aquelas envolvendo pessoal. Em contraposição, as organizaçōes nacionais tendem a concentrar a maioria das decisóes no nivel 3 , ou seja, no nivel de gerência ou escaláo intermediário, exceto as que requerem gastos orçamentários. Quase năo se verifica a descentralização de decisర́es a nivel de setor ou área administrativa.

No que diz respeito à amostra brasileira em geral, merece atenção o fato de que são poucas as decisర̃es que são tomadas quer. nos níveis mais altos da hierarquia quer nos mais baixos. Neste ponto, os resultados brasileiros se assemelham mais aos da Alemanha do que aos da Grã-Bretanha, havendo poucas decisóes delegadas aos níveis inferiores da hierarquia. Dos 19 tipos de decisoes, nenhum é delegado ao nível operacional. As empresas estrangeiras chegam a descentralizar algumas decisóes de marketing, produção, compras, aos niveis inferiores na hierarquia, e tendem a reter algumas decisoes nos níveis mais altos, como as administrativas e estratégicas. As de propriedade nacional, pelo contrário, não delegam responsabilidades aos níveis mais baixos e há uma tendência a concentrar poder decisório nos níveis médios.

Da maneira como os resultados para as organizaçoes nacionais se configuram, torna-se razoável aventurarmos algumas explicaçóes. Primeiro, como a maior parte das organizaçōes nacionais se constituía de empresas familiares, ${ }^{52}$ é provável que a concentração da maioria das decisôes no escalão intermediário seja um reflexo da falta de distinção entre propriedade e controle. No modelo familiar de gestáo, muito comum no Brasil, o poder de decisáo fica com o chefe da familia ou com parentes. Normalmente, filhos ou genros tomam a liderança no segundo escalá, ou seja, se o chefe da família se encarrega das decisoes mais importantes, os filhos e/ou ele próprio sâo os responsáveis por decisóes relativas a áreas funcionais e mesmo às mais rotineiras. De modo que, quando o pai ocupa a presidência, os filhos ou parentes ocupam o escalão imediatamente abaixo. Conseqüentemente, os graus de autonomia e responsabilidade decisória podem ser equivalentes tanto a nível de diretoria quanto a nível de gerência. Este modelo de gestáo poderia vir a explicar a concentração de várias decisóes no nível 3 , como indicado na tabela $7 .^{53}$

E importante observar que este é um aspecto bastante interessante da centralização. Apesar de a autorização das decisóes se processar no nível imediatamente abaixo da diretoria, ainda assim observa-se a característica centralizadora das organizaçóes nacionais, uma vez que as decisões mais operacionais não são delegadas a áreas de competência. E neste ponto que os dados refletem a reduzida participação da camada inferior da hierarquia no processo decisório. A descentralização para estes níveis é com certeza desencorajada e em muitos casos justificada em função da estratificação social que se estende para a organização. De fato, estes aspectos vêm sendo constatados por alguns estudos interculturais envolvendo o Brasil. Por exemplo, na pesquisa de Hofstede, ${ }^{54}$ o Brasil, comparativamente, está entre os países que apresentam maior diferença em, poder entre superiores e subordinados. De maneira semelhante, Bass ${ }^{55}$ encontrou que os administradores brasileiros preferem subordinados mais passivos e menos participativos.

Nas organizações da amostra nacional, observamos que os que ocupam posiçóes na cúpula não somente decidem sobre vários assuntos, dos mais complexos ao mais simples, mas também têm a responsabilidade última por funçóes de natureza diversa. Por exemplo, é comum o gerente de produção se encarregar da parte relativa à compra de materiais e dos problemas de pessoal; também é normal que o gerente de marketing e o gerente de expansão sejam a mesma pessoa. Além disso, encontramos situações onde havia uma pessoa na gerência de produção e compras e outra na gerên cia de produçáo e pessoal. Estes aspectos, típicos da divisáo do trabalho em empresas familiares, nos chamou a atenção durante a pesquisa de campo pela dificuldade que tivemos em verificar a especialização da maneira como o conceito é definido pela equipe de Aston. As diversas replicaçóes desta pesquisa registram a presença de um especialista na organização quando existe uma pessoa que é responsável apenas por determinada função. No caso das organizaçóes nacionais, não conseguimos identificar especialistas tal e qual eles sáo definidos pelo grupo de Aston, pois a maioria dos gerentes normalmente atua e é responsável por mais de uma área.

A tabela 9 ilustra esta característica básica das empresas familiares, onde os donos fazem quase tudo. A primeira coluna indica o número de generalistas por organizaçóes, isto é, aqueles que săo responsáveis por mais de uma funçăo. A coluna 2 mostra quantas funçóes são exercidas por mais de uma pessoa. Assim, na organização número 1, quatro indivị́duos desempenham mais de uma funçăo e ainda seis funçóes estáo sob a responsabilidade de mais de uma pessoa. Todas as organizaçóes na tabela 9 sáo nacionais, uma vez que o "generalismo" nao foi observado entre as multinacionais. 
Tabela 9 - Administração geral nas organizaçðes $-{\text { (amostra nacional })^{1}}^{1}$

\begin{tabular}{ccl}
\hline $\begin{array}{l}\text { Organizaçōes } \\
\text { (Propriedade } \\
\text { nacional) }\end{array}$ & $\begin{array}{c}\text { Nọ de } \\
\text { generalistas }\end{array}$ & \multicolumn{1}{c}{$\begin{array}{c}\text { Funções exercidas por } \\
\text { mais de uma pessoa }\end{array}$} \\
\hline 1 & 4 & $1,10,12,13,14,16=6$ \\
2 & 1 & $10,11=2$ \\
3 & 1 & $1,3,5,9,11,14=6$ \\
4 & 5 & $3,4,5,6,7,8,10,13=8$ \\
5 & 5 & $1,2,8,9,10,11,12,13,14,16=10$ \\
6 & 5 & $2,7,10,11,15,16,=6$ \\
7 & 5 & $2,3,7,10,13=5$ \\
8 & 4 & $1,10,11,16=4$ \\
9 & 3 & $1,2,3,10,12,14,16=7$ \\
10 & 4 & $14,16=2$ \\
11 & 1 & $1,2,8,11,12,13,15=7$ \\
12 & 5 & $2,3,10=3$ \\
13 & 3 &
\end{tabular}

${ }^{1}$ Ver Ane $\mathrm{xo}^{3}$ para detalhes sobre a numeração de especialismos.

Estes dados representam não só as características internas da organização familiar, mas certamente retratam uma situaçao comum nas organizaçбes brasileiras, diferentemente de países como a Inglaterra, onde as responsabilidades são rigidamente delimitadas, podendo o funcionário ser punido ou processado se comete falhas no desempenho de funçóes para as quais ele ño dispóe de qualificação. No Brasil, a delimitação de responsabilidadès é ambígua. Nos niveis hierárquicos mais altos, a auto-suficiência decisória faz com que todo mundo seja especialista em quase tudo e, nos niveis hierárquicos inferiores, há os "quebra-galhos" que resolvem problemas das mais diversas naturezas. Assim, os limites entre as funções podem ser claramente definidos no papel, mas, na prática, a administração vem-se apoiando naquelas poucas pessoas que podem resolver ou fazer quase tudo.

Quanto à formalização, como os dados agregados não diziam muito além da importância de papéis definindo normas e políticas para a amostra brasileira, resolvemos desdobrar a escala em três componentes básicos, segundo seu uso. A tabela 10 mostra a proporção de documentos que são usados nas organizaçôes para definiçấo de funçôes, comunicações e controle de desempenho.

Tabela 10 - Características da formalização: uso de diferentes tipos de documentação

\begin{tabular}{|c|c|c|c|}
\hline \multicolumn{4}{|c|}{ Escalas } \\
\hline Organizaçōes & $\begin{array}{c}\text { Definiçăo de papéis } \\
\text { e funç̧̃os } \\
(\%)\end{array}$ & $\begin{array}{c}\text { Transmisş̃o de } \\
\text { informações } \\
(\%)\end{array}$ & $\begin{array}{c}\text { Controle de } \\
\text { desempenho } \\
\text { (\%) }\end{array}$ \\
\hline Multinacionais & 96 & 89 & 97 \\
\hline Nacionais & 77 & 54 & 75 \\
\hline
\end{tabular}

Diferentemente das organizaçס̄es britâncias, que têm menos documentos definindo papéis e funções, manuais, políticas e programas escritos, as organizaçoes brasileiras, tanto as subsidiarias de multinacionais quanto as nacionais, fazem uso freqüente dos três tipos de documentos.
A grande maioria das organizaçбes no primeiro grupo emprega documentos de todos os três tipos. As organizafóes nacionais têm $35 \%$ a merios de documentos para comunicação, $19 \%$ a menos de documentos definindo regras gerais para a organizaçáo e $22 \%$ a menos de documentos para controle de desempenho. $E$ interessante notar que ambos os tipos de organizaçoses empregam poucos documentos para propósitos de comunicação, em comparação com o número de papéis destinados a garantir conformidade a regras, e os que definem níveis de desempenho para funcionários de nivel médio e trabalhadores. Além disso, os resultados expresssam alguns aspectos interessantes sobre valores e padrões de comportamento brasileiros. Tradicionalmente, a formalização na administraçáo brasileira vem servindo aos propósitos de impor limites e controlar comportamentos mais do que à comunicação interna e externa. Nas comunicações, ainda predomina a preferência pelos contatos verbais e diretos. $^{56}$

\section{DISCUSSÃO E CONCLUSÃO}

No in ício do artigo fizemos referência à nossa intenção de examinar a estrutura através de dois paradigmas opostos. $\mathrm{O}$ nosso interesse era testar a importância relativa da lógica contingencial em contraposiçáo à tese sobre as particularidades da cultura que terminam por moldar a organizaçáo de modo a preservar padróes e comportamentos prevalentes. Não dispúnhamos de medidas diretas dos aspectos sócio-culturais, mas esperávamos observar os seus efeitos indiretamente, comparando as médias das variáveis estruturais da amostra brasileira com as de outros países. Apesar de os dados agregados não fornecerem informaçóes a este respeito, levantamos alguns aspectos específicos sobre as organizaçôes nacionais através da análise separada de cada um dos subgrupos (nacional e estrangeiro).

De um modo geral, as evidências encontradas apóiam parcialmente cada um dos argumentos. Nos termos da teoria da contingência, podemos dizer que, no caso do Brasil, houve transferência de idéias na medida em que as organizaçбes maiores são mais complexas em termos de diferenciação, trabalho profissional e padronização de procedimentos. Seria ingênuo supor, no caso de organizaçóes que cresceram através de expansão geográfica, que a administração pudesse ser feita a distância sem o uso de controles formais. Da mesma maneira, torna-se difícil imaginar a administração eficiente de 5 mil empregados sem o uso de controle burocrático. ${ }^{57}$ Grandes organizações parecem requerer divisão do trabalho fundamentada na especialização funcional e regras gerais formalizadas, independentemente de onde estão localizadas, se na Suécia ou no Japão, no Brasil ou Alemanha. Isto se aplica aos nossos dados e em particular às multinacionais; esta pesquisa também mostra a importância destas organizaçбos como agentes de difusáo de modelos do mundo industrializado.

Por outro lado, as empresas nacionais apresentam práticas administrativas que se prendem a razóes histórico-culturais, na medida em que sua estrutura relembra os valores e padrões organizacionais das unidades patrimoniais agrárias. $\mathrm{O}$ modelo familiar de gestáo não admite 
delegação de decisøes fora do âmbito da familia; geralmente poucas pessoas decidem tudo. A divisáo do trabalho é atípica, considerando-se o modelo weberiano, os poucos que decidem tudo também têm responsabilidade pelo controle de atividades de natureza diversa. Ainda, as tarefas parecem ser definidas de maneira ambígua, uma vez que várias pessoas têm responsabilidade pela mesma função. Como as decisōes se restringem à esfera familiar ou à cúpula, supoe-se que os que estão nos demais segmentos não merecem confiança ou não têm competência. Tudo indica que neste sistema não há muito lugar para os que ocupam os níveis inferiores da hierarquia nem para os especialistas; nas leis da organizaçáo familiar o que mais importa é o parentesco, a confiança e a lealdade. Não obstante, não queremos sugerir que as organizações da amostra nacional se encontram completamente à margem do mundo moderno. Por exemplo, a formalização é uma das principais formas de articulação com o mundo moderno, sem que se destruam valores e atitudes prevalentes. ${ }^{58} \mathrm{Na}$ amostra nacional, as políticas, regras e funçōes são definidas por escrito e existe registro para controle de desempenho. Logo, nestas organizaçбes as funções são diferenciadas, existe a divisão em departamentos e a representaçáo no organograma, mas a maneira como elas funcionam ou usam a estrutura é uma outra questão. Portanto, as semelhanças com o mundo industrializado referem-se mais ao fenótipo, enquanto no seu genótipo elas funcionam de modo genuinamente brasileiro.

Sendo assim, isto nos traz de volta ao dilema da administração brasileira. A hierarquia, definindo-se principalmente em termos de autoridade, sem a correspondência devida em especializaçáo funcional, se de um lado pode satisfażer demandas de natureza sócio-culturais, de outro pode vir a enfraquecer a legitimidade do sistema e a capacidade de competir. Este é um ponto que achamos que merece atenção de pesquisas futuras.

Entretanto, é preciso ressaitar que as nossas conclusóes sáo limitadas pela amostra e pelo próprio modelo conceitual e metodológico que utilizamos nesta pesquisa. Em relação a isto, temos algumas observaçoes a registrar.

\section{O USO DA METODOLOGIA DE ASTON EM PESQUISAS INTERCULTURAIS; ALGUMAS IMPLICAÇÕES METODOLOGICAS}

A análise intercultural de organizaçбes é certamente uma área de estudos emergente, cuja importância deve atingir o seu cume ainda nesta década. Num simpósio sobre administraçáo intercultural no Canadá, em 1981, Nancy Adler ${ }^{59}$ define este campo do conhecimento como sendo o estudo do comportamento de pessoas em organizaçбes em diferentes culturas e naçóes. Três aspectos seriam relevantes para a administração intercultural: a explicaçáo e descriçáo do comportamento organizacional den. tro do seu contexto cultural específico; a análise comparativa de organizaçбes em diferentes culturas ou sociedades; e as interaçóes entre pessoas de diferentes paises quando trabalhando numa mesma organização. Definida a área de interesse, a questáo que se segue refere-se d̀ extensáo na qual as pesquisas interculturais têm contribuído para a compreensão das diferenças e semelhanças en- tre organizaçóes em sociedades distintas e dentro da própria cultura. Ao avaliar o estado da arte em 1970, K. Roberts, ${ }^{60}$ referindo-se ao amontoado de pesquisas sem in terconecçáo no enfoque ou unidade de análise, compara a pesquisa intercultural a um grande elefante onde cada pesquisador trabalha indeperdentemente e faz conjeturas sobre o que seria determinada parte, sem, contudo, entender o seu todo. Desde essa época, os progressos não foram substanciais; numa revisáo recente, a autora afirma que os pesquisadores se acham diante do mesmo dile$\mathrm{ma}$, tentando em vão imaginar o que seria um elefante de maiores dimensôes. ${ }^{61}$

Além do parcialismo das abordagens, há outras razões pelas quais estes estudos não têm contribuido relevantemente para o entendimento do impacto da cultura na forma $e$ funcionamento das organizaçбes. Bertero faz algumas observações muito pertinentes sobre isto; afirma - autor que a interface organização/cultura não chega sequer a ser considerada, principalmente quando se trata de pesquisas que envolvem comparaçáo entre culturas homogêneas. Com efeito, a maioria das pesquisas vem-se restringindo às sociedades anglo-saxônicas, aos países europeus, ou compara subsidiárias de multinacionais. É evidente que, no primeiro caso, as chances sáo de se encontrar mais semelhanças do que diferenças, uma vez que a própria estratégia da pesquisa nao permite o contraste entre culturas. Bertero ${ }^{62}$ argumenta que os estudos em multinacionais sofrem esta mesma restriçấo, na medida em que envolvem fundamentalmente comparações entre subculturas. Diversamente, poderíamos argumentar que isto se deve à divisáo de interesses da teoria intercultural; de um lado, os universalistas interessados nas características homogêneas e, de outro, os culturalistas atentos às diferenças culturais. Mas, ainda assim, é claro que, se a maioria das pesquisas focalizar apenas as similaridades, teremos uma teoria das convergências e saberemos menos a respeito da interface organização/cultura.

Não obstante, não podemos esperar muito de um campo de estudos que ainda é emergente. Em 1964, Crozier $^{63}$ observa que as diferenças sócio-culturais nao haviam sequer despertado curiosidade dos estudiosos de organizaçoes. Numa revisáo recente, Beres \& Portwood ${ }^{64}$ afirmam que até 1970 a maioria dos estudos eram anedóticos e exploratórios, com pouco desenvolvimento teóri$\infty$. Os trabalhos que se seguiram trouxeram algumas inovações conceituais e metodológicas, mas não o suficiente para resolver os problemas críticos.

Os autores apontam uma série de limitaçóes comuns a este tipo de pesquisa, algumas das quais se aplicam também à presente pesquisa. Por exemplo, a grande maioria dos estudos interculturais inclui poucos países e utiliza pequenas amostras limitadas a determinadas regiбes. Este tipo de restrição se aplica também à nossa pesquisa, colocando em questro a representatividade dos resultados para o Brasil. No caso de países como a Inglaterra ou o Japæo, onde existe homogeneidade econômica e social, o fato de a coleta de dados se restringir a determinada região não traz conseqüências importantes para a generalizaçăo. Em relação ao Brasil, a situação é diferente devido a heterogeneidade sócio-conômica entre regiøes. Neste caso, mesmo a estrutura industrial poderia influenciar os resultados, na medida em que as empresas familia- 
res ou estatais ou subsidiárias de multinacionais fossem representativas da economia da regiáo.

Ainda no que diz respeito à amostra, um outro ponto problemático é a obtençá de amostras equivalentes. Com relaçáo d̀s replicaçóes do estudo de Aston, o próprio esquema da pesquisa, incluindo organizaçoes de vários tipos, tamanhos' $e$ status, traz dificuldades quanto a equivalência entre as amostras. A conseqüência disto é que amostras das replicaçбes não têm mostrado a necessária correspondência quanto às características mencionadas. Além do mais, a própria amostra sofre as limitaçoes ditas pelo contexto - por exemplo, em Minas Gerais a maioria das organizaçóes de propriedade nacional tem seu escritório central em Belo Horizonte. Logo, as organizaçōes da presente pesquisa ño poderiam apresen. tar a necessária variação quanto ao status. De maneira geral, as replicaçoes incluem também subsidiárias de multinacionais. Embora no estudo de McMillan, ${ }^{65}$ comparando organizações no Canadá, EUA a Inglaterra, a presença de multinacionais não tenha produzido alteraçoes significativas nos resultados, no nosso caso resolvemos analisar os resultados separadamente em subgrupos. Isto, com efeito, nos mostrou que as organizaçóes nacionais apresentavam características próprias e que as multinacionais tendiam a se conformar mais com os padróes de administração dos paises industrializados. Caso os resultados náo fossem separados, poderíamos enganosamente reforçar a hipótese da convergência organizacional. Por este motivo, consideramos mais produtivo para pesquisas interculturais a estratégia de pesquisa que utiliza grupos equivalentes de empresas nacionais e estrangeiras em número e no tamanho, principalmente se houver interesse específico no impacto das multinacionais. Se o objetivo da pesquisa consistir em obsservar o impacto de culturas diferentes em organizaçóes, torna-se mais adequada não incluítas.

Embora tais dificuldades mostrem as limitaçóes da presente pesquisa, algumas delas sao contornáveis, na medida que o pesquisador esteja atento aos fatores que podem vir a interferir nos resultados e levar a conclu. sćes enganosas ou obscuras. Porém, muitos obstáculos na análise de dados poderiam ser evitados com o aperfeiçoamento da estratégia de pesquisa e maior rigor na amostragem. Gostaríamos de ressaltar, ainda, que estes não são os problemas mais difíceis da pesquisa intercultural. Uma das razóes fundamentais pelas quais os estudos comparativos não têm apresentado contribuiçóes muito significativas para o entendimento dn impacto da cultura nas organizaçóes diz respeito, primeiro, à conceituação e medida das variáveis culturais; segundo, não se sabe ainda de que forma estariam ligadas às organizacionais. Alguns autores vêm usando o conceito de cultura como sinômino de naçăo, contornando as exigências quanto d̀ definiçăo e medida, mas esta alternativa se toma imediatamente inadequada quando deparamos com a situaça na qual as fronteiras entre nação e cultura não sáo coincidentes - como, por exemplo, no caso do Canadá e da Iugoslávia. Além disso, as explicaçôes baseadas na nacionalidade tornam-se tautologicas, na medida em que comparam determinada realidade consigo própria. De fato, a maioria das pesquisas que usam a metodologia de Aston sofre esta limitacáo. Por exemplo, Child \& Kieser $^{66}$ atribuem o alto indice de centrali- zação das empresas alemas em comparação com as britânicas às relaçóes de autoridade vigentes na Alemanha. Na sociedade ocidental, os alemães se distinguem por valorizar o respeito à autoridade e preferência por estilos de gerência mais controladores do que participativos. A natureza das relaçós de autoridade, a ênfase na estabilidade de hierarquia, dizem os autores, certamente refletem no processo decisorio e estrutura organizacional. Da mesma maneira, Azumi e McMillan ${ }^{67}$ explicam a média mais alta de centralizaçato das organizaços japonesas em relaçăo às britânicas. As diferenças șo aí atribuídas ao caráter único da sociedade japonesa, às práticas gerais de recrutamento e promoção em organizaçoes. Já Kuc e colaboradores $^{68}$ recorrem aos fatores político e econômico para explicar o nivel de centralizaçio comparativamente mais alto das organizaços polonesas. As diferenças são atribuidas ao envolvimento do Estado no planejamento das empresas. Naquele país, os objetivos das organizaços em termos de alocação de recursos, preço, investimento, stáo estabelecidos pela comissáo de planejamento central. Reclamaçóes diretas quanto aos planos não são possíveis, uma vez que as decisóes são tomadas externamente. Qualquer reivindicaçáo ou interferência no processo decisório se dá apenas de maneira indireta, principalmente através de meios de comunicaç⿰丿. No caso da presente pesquisa, sugerimos que o problema de delegaçáo de decisóes aos níveis hierárquicos inferiores poderia estar associado a três fatores básicos: primeiro, ao próprio sistema de gestáo familiar das empresas nacionais; segundo, ao autoritarismo vigente na sociedade brasileira em geral, que estimula maior rigidez nas relaçóes de autoridade favorecendo e justificando a centralização de decisós; terceiro, há a questão da divisáo da socie. dade èm central e marginal, que se repete dentro das organizaçoses, tomando a descentralização realmente problemática.

Como se nota, a maioria das replicaçoes atribuiu as diferenças encontradas a fatores de natureza política, econômica ou social, partindo da suposição implícita ou explícita de que estes fatores representam uma extensáo do nivel macrossocial. A falta de consistência entre os aspectos enfatizados pelas replicaçoes nos leva a questionar a propriedade do esquema conceitual e metodológico da equipe de Aston, quando se intenciona capturar as manifestaçб̃es da cultura em organizaçóes num primeiro plano e, num segundo plano, a comparaçáo entre sociedades. Analisando de um ponto de vista estritamente metodológico, torna-se difícil transcender os limites a escala de Aston que foram elaborados apenas para medir dimensóes estruturais. Neste ponto, elas sấo satisfatórias mesmo quando o interesse reside em analisar apenas a estabilidade das relaçós entre contexto e estrutura. De um outro ângulo, seria ingênuo estudar-se as organizaçoes brasileiras apenas sob a b́tica da convergência, quando se sabe da natureza contraditória e dualista de nossa sociedade. Embora o presente estudo tenha mostrado alguns aspectos contraditórios das organizaçoes no Brasil, poderíamos ter chegado a situaçós mais concretas se dispuséssemos de um modelo que, além da estrutura, examinasse mais profundamente como as organizaçoes funcionam.

Conforme concluímos antes, é mais fácil se encontrar semelhanças naquilo que pode ser diretamente transplantado como, por exemplo, a tecnologia ou a estrutura 
física das coisas. A ênfase nestes aspectos poderia, portanto, vir a reforçar a noção da convergência, sem que o descompasso entre estrutura, funcionamento ou uso seja sequer questionado. $O$ fato de que existem estruturas semelhantes nao significa que elas sejam usadas do mesmo jeito ou que as relaçóes que definem o funcionamen. to sejam as mesmas. Por esta razão, sugerimos que a ênfase dos estudos interculturais deve ser dirigida também a processos internos da organização (decisão, comunicaçōes) e às relaçбós com autoridade, colegas e clientes. Talvez neste caso fosse possível captar diretamente o jei. tinho ou o autoritarismo.

Por outro lado, torna-se difícil captar processos e relaçōes através de uma abordagem nomotética que produziria apenas uma "fotografia" da organizaçăo. A ênfase nestes aspectos exigiria um "filme" e implicaria, portanto, uma mesma abordagem ideográfica, num estudo intensivo de casos, onde se tentasse primeiramente entender a interface organização e cultura específica. $O$ estudo de casos poderia envolver a comparaçáo entre subculturas organizacionais - por exemplo, subsidiárias de multinacionais e empresas de propriedade nacional. $O$ uso da metodologia nomotética exigiria certos cuidados essenciais; por exemplo, a amostra deveria ser representativa em relação à população, o uso de uma equipe multinacional traria contribuicóes mais efetivas quanto ao entendimento das singularidades organizacionais em cada pais e, finalmente, as organizaçoes deveriam ser equivalentes em número, tamanho e em outras características que fossem relevantes à pesquisa.

Com esta estratégia de pesquisa estamos sugerindo que, antes de entendermos em que aspectos organizaçбes em sociedades diferentes se aproximam ou diferem entre si, precisamos primeiramente conhecer de que forma a cultura ou sociedade específica permeiam a vida organizacional. A nosso ver, somente assim seria possível desenvolver uma teoria intercultural que fosse menos ingênua e superficial, e ao mesmo tempo capaz de explicar as diferenças entre organizaçóes de maneira compatível com a realidade específica de cada sociedade.

Anexo 1

Dependência

Dependência: reflete as relaçoes da organizaçáo com o seu ambiente social e econômico, com fornecedores, clientes, competidores, a matriz e outras organizaçoes políticas e sociais (Pugh \& Hickson, 1976, p. 98).

Escala n? 12-10

Status da unidade organizacional

Filial

Escritório de filiais ou escritório de fábrica

Pontos

Subisidária

Unidade principal

Escala n? 12-11

Representação da unidade no processo político

Organização náo é representada na cúpula

Organizaçáo é representada na cúpula da unidade local mas não na cúpula da organização

Organizaçáo é representada na cúpula da organização

Pontos

1

3

Escala n? 18-03

Integração com fornecedores

Nenhum laço de propriedade. (pedidos de acordo com uma rotina simples)

Nenhum laço de propriedade (pedidos, propostas ou contratos únicos)

Nenhuma propriedade e contratos de curto prazo, inventário e numerário

Nenhuma propriedade e contratos anuais, categorias fixas

Propriedade e ligaçóes contratuais

Propriedade e compromisso de fornecimento

Escala n? 18-05

Resposta em volume de produção

Produtos para estoque

Produtos para estoque sob encomenda

Produtos sob encomenda

Produtos sob encomenda sendo permitido

ao cliente programar ou desistir do pedido

Pedidos sujeitos à programaçáo pelo cliente com desistência permitida

Pontos

Escala n? 18-08

Integração com clientes: tipo de elo com a clientela

Pedidos simples

Contratos regulares

Contratos de longo prazo (dois anos)

Propriedade

Escala n? 18-09

Integraçāo com clientes: dependência da organizaçāo de seus maiores clientes

Dependência menor (menos do que $10 \%$ dos produtos sáo vendidos a um consumildor)

Dependência média (mais do que $10 \%$ dos produtos são vendidos a um consumidor)

Dependência maior (mais do que $50 \%$ dos produtos são vendidos a um consumidor)

Dependência total (toda a produçáo é absorvida por um consumidor)

Pontos

Escala n? 18-10

Integraçāo com clientes: dependência dos grandes clientes da organização

A organizaçáo é fornecedor menor (menos do que $10 \%$ do item particular)

A organizaçáo é fornecedor médio (mais do que $10 \%$ do item particular)

A organizaçáo é fornecedor maior (mais do que $50 \%$ do item particular)

A organizaçáo é fornecedor com direito exclusivo
Pontos 
Anexo 2

Formalização

Formalização: refere-se à extensáo na qual regras, procedimentos, instruçōes e comunicaçóes ș́o escritos e (em alguns casos) o seu grau de aplicação e distribuiçăo (Pugh \& Hickson, 1976, p. 71-3).

\section{Escala no. 53-01}

Definição de papéis

1. Quem tem contratos escritos de emprego

2. Proporção de empregados que têm manuais

Nenhum

Poucos empregados

Muitos empregados

Todos empregados

3. Número de manuais

Nenhum

Um

Dois

Três

Quatro ou mais

4. Organograma

5. Instruçס̄es escritas de trabalho e procedimentos disponíveis para 0 trabalhador

6. Termos de referência escritos ou descrições de cargos

7. Políticas escritas

8. Esquemas de produção ou programas de trabalho

9. Relatórios ou programas de pesquisa

Escala n? 53-02

Transmissáo de informaçōes

10. Aprovação por escrito da administração para certas decisóes

Pontos

$0 / 1$

1

2

3

0

1

2

3

4

$0 / 1$

$0 / 1$

$0 / 1$

$0 / 1$

$0 / 1$

$0 / 1$

Pontos

11. Esquema de sugestర̃es

12. Memorandum

13. Notificação de con trataçס̃es de operários, funcionários

14. Minutas para reuniáo de executivos de alto escaláo

15. Relatórios de reunióes

16. Agenda para reunião de executivo de alto escaláo

17. Agenda para reunióes de fluxo de produção ou de trabalho

18. Minutas de reunióes de fluxo de produção ou de trabalho

19. Relatórios escritos submetidos aos membros nas reunióes do fluxo de pro. dução ou de trabalho

20. Documentos disponíveis aos trabalhadores sendo contratados, sobre os benefícios a que têm direito

21. Formulários de demissáo ou relatório registrando ou comunicando a demissão

22. Jornal interno
Escala n? 53-03

Registro de desempenho

23. Documentos sobre inspeçâo (por exemplo, relatórios, certificados, cartáo de qualidade etc., registrando resultados positivos e negativos)

24. Documentos de avaliação do trabalho (estudo do trabalho)

25. Documentos sobre manutenção de equipamentos

$0 / 1$

26. Registro de desempenho de operários

27. Registro do tempo de trabalho de operários

$0 / 1$

$0 / 1$

28. Documentos declarando tarefas feitas ou a serem feitas em uma unidade de produção

$0 / 1$

29. Registro de requisição de material

$0 / 1$

30. Formulários para pedidos de despesa acima de determinadas quantias

$0 / 1$

31. Requisição para contratação de operários

$0 / 1$

32. Fichas de inscriçăo ou formulário de contrataçáo de trabalhadores

$0 / 1$

33. Cartão de ponto

$0 / 1$

Itens nâo incorporados nas escalas $n$ ? 53-01, 53-02 e 53-03

Pontos

34. Formulário de apelo contra demissão

$0 / 1$

35. Documentos identificando o produto

36. Notạs para registro de despacho de produtos

37. Procedimentos escritos para negociação com sindicatos, ocorrência de greves, reclamações etc.

$0 / 1$

$0 / 1$

$0 / 1$

38. História escrita dả organização
Pontos

\section{1}


9. Registrar e controlar recursos financeiros

10. Controlar o fluxo de produçáo

11. Controlar a qualidade de materiais equipamentos e produtos

12. Determinar e projetar métodos de produção

13. Projetar novos produtos, equipamentos e processos

14. Desenvolver e executar procedimentos administrativos

15. Tratar de problemas jurídicos e de segurança

16. Adquirir informaçōes na área operacional

$0 / 1$

$0 / 1$
17. Custos, isto é, qual o sistema de custos aplicado

$$
0-5
$$

18. Inspeçáo, isto é, quais os itens, processos etc. do sistema de inspeçăo seráo aplicados

19. Operaçóes onde serão aplicados estudos de trabalho

$0-5$

$0-5$

$0-5$

20. Planos a serem desenvolvidos gundo os planos desenvolvidos

\section{Anexo 4}

Centralização

Centralizaçầo: refere-se ao nível hierárquico no qual as decisões são autorizadas, mesmo que posteriormente sejam homologadas em um nivel superior. Os pontos em centralização são atribuídos num total de 37 decisoes que envolvem várias atividades organizacionais. As decisões autorizadas acima da unidade organizacional sáo atribuídos 5 pontos; no nível do executivo chefe, 4 pontos; no nivel departamental, 3 pontos; no nivel de área ou setor, 2 pontos; nível de supervisáo, 1 ponto, sendo zero atribuído às decisóes no nivel operacional (Pugh \& Hickson, 1976, p. 73).

\section{Escala 54-00}

\section{Decisöes}

1. Qualificação da força de trabalho

2. Seleçấo de trabalhadores

3. Promoção de trabalhadores

4. Representaçấo da organização em disputas de trabalho (representaçóes judiciais e sindicais)

5. Número de supervisores

6. Seleção de supervisores

7. Promoção de supervisores

8. Salário de supervisores

9. Despesas com itens não-orçamentários de capital

10. Despesas com itens não-orçamentários de receita

11. Seleção do tipo ou marca para novo equipamento

12. Horas extras a serem trabalhadas

13. Datas de entrega ou prioridade de pedidos

14. Novo produto ou serviço

15. Novos mercados a serem desenvolvidos e cobertos

Pontos atribuidos (amplitude)

$$
\begin{aligned}
& 0-5 \\
& 0-5 \\
& 0-5
\end{aligned}
$$

22. Demịssão de operários

23. Demissáo de supervisores

24. Métodos de seleção de pessoal

25. Métodos de treinamento

26. Procedimentos de compra

27. Fornecedores de materiais a serem usados

28. Métodos de trabalho a serem usados

29. Maquinaria ou equipamento a ser usado por um tipo de trabalho

30. Alocação de trabalho entre trabalhadores disponiveis

31. Atividades de bem-estar social a serem oferecidas

32. Preço do produto

33. Modificaçáo de responsabilidades de áreas funcionais

34. Modificação de responsabilidades de áreas de apoio

35. Criação de um novo departamento (apoio ou linha)

36. Criação de um novo cargo

37. Quem assume tarefas ou responsabilidade na ausência do presidente ou diretor

$0-5$

$0-5$

$0-5$

$0-5$

$0-5$

$0-5$

$0-5$

$0-5$

$0-5$

$0-5$

$0-5$

$0-5$

$0-5$

$0-5$

$0-5$

$0-5$

$0-5$

\footnotetext{
-Adaptação do trabalho apresentado na First International Conference of Comparative Historical and Critical Analysis of $\mathrm{Bu}$ reaucracy, em Zurique, setembro 1982.
}

$0-5$

$.0-5$

$0-5$

$0-5$

$0-5$

$0-5$

$0-5$

${ }^{1}$ Udy, S.H: Bureaucracy and rationality in Weber's organization theory: an empirical study. American Sociological Review, 24: 791-5, 1959; Hall, H.R. Intraorganizational structural variation: application of the bureaucratic model. Administrative Science Quarterly, 7(3):295-308, 1962.

2 Pugh, D.S.; Hickson, D.J.; Hinings, C.R. \& Turner, C. Dimen-

16. Objetivos quanto a extensáo e tipo de mercado (campo operacional) a ser atingido

$0-5$ sions of organization structure. Administrative Science Quarterly, 13(1) 65-105, 1968; Pugh, D.S.; Hickson, D.J.; Hinings C.R. \& Turner, C. The context of organization structures. Administrative Science Quarterly, 1491-114, 1969. 
${ }^{3}$ Lammers, C.J. \& Hickson, D.J. ed. Organization alike and unlike: international and inter-institutional studies in the soctology of organizations. London, Routledge \& Kegan Paul, 1979; Hickson, David J. \& McMillan, C., ed. Organization and nation; the Aston programme IV. London, Gower, 1981.

${ }^{4}$ Shenoy, S. Organization structure and context: a replication of the Aston study in India. In: Hickson, D.J. \& McMillan, C., ed Organization and nation. Farnboroughs Hampshire, Gower, 1981. p. 132-54

${ }^{5}$ Badran, M. \& Hinings, C.R. Strategies of administrative control and contextual constraints in a less developed country: the case of Egyptian public enterprise. Organization Studies, 2(1): $3-21,1980$.

${ }^{6}$ Ayoubi, Z.M. Technology, size and organization structure in a developing country: Jordan. In: Hickson, D.J. \& McMillan, C. ed. op. cit. p. 95-114.

${ }^{7}$ Keer, C.; Dunlop, J.T.; Harbson, F. \& Myers, C.A. Inäustrialism and industrial man. Cambridge, Massachusetts, Harvard University Press, 1964.

${ }^{8}$ Chandler, A.D. The United States: seedbed of maniagerial capitalism. In: Chandler, A.J. \& Daems, H., ed. Managerial hiearchies. London, Harvard University Press, 1980. p. 9-40.

${ }^{9}$ Clegg, S. \& Dunkerley, D. Organization class and control London, Routledge \& Kegan, 1980.

10 Hickson, D.J. \& McMillan, C. op. cit.

11 Silverman, D. The theory of organisations. New York, Basic, 1970; Child, J. Organization structure, environment and performance: the role of strategic choice. Sociology, $6: 1-22,1972$.

12 Van Doorn, J. Organizations and the social order: a pluralist approach. In: Lammers, C.J. \& Hickson, D.J., ed. op. cit. p. 61-75; Aiken, W. \& Bacharach, S.P. Culture and organizational structure and process: a conparative study of local government administrative bureaucracies in the Wallon and Flemish regions of Belgium. In: Lammers, C.J. \& Hickson, D.J. ed. op. cit. p. 215-50.

13 Hickson, D.J.; McMilian, C.J.; Azumi, K. \& Horvath, D. Grounds for comparative organization theory In: Lammers, C.J. \& Hickson, D.J. ed. op. cit. p. 25-41.

14 Crozier, M. Cultural determinants of organizational behavior. In: Negandhi, A.R., ed.Modem organizational theory. Kent, The Kent State University Press, 1973.p. 219-28.

15 Child, J. \& Tayeb, M. Theoretical perspectives in cross-national organizational research. International Studies of Management \& Organization, 12(4):23-72, 1982/83.

${ }^{16}$ Hofstede, G. Culture's consequences. London, Sage, 1980.

17 Sorge, A. Cultured organizations. Intemational Studies of Management Organization, 12(4):106-38, 1982/83.

${ }^{18}$ Child, J. \& Tayeb M. op. cit.

${ }^{19}$ Sorge, A. op. cit.

${ }^{20}$ Id. ibid.

21 Burrel, G. \& Morgan, Gareth.Sociological paradigms and organizational analysis. London, H.E.B., 1979.

22 Dore, R. British factory - Japonese factory. London, George Allen, 1973. Segundo o autor. "The later industrialization be- gins, the brigger the organizational leap; the more likely industry is to begin with rationalized bureaucratic forms of organization including personnel managers operating objectives recruitment and promotion schems the more so if, as is likely, the State plays a direct role in the industrialization process through state corporations or partnerships schems" (p.416).

${ }^{23}$ Wahrlich, Beatriz M. de Souza. Reforma administrativa federal brasileira: passado e presente. Revista de Administraçäo Públi. ca, 8:27-75, 1974.

24 Dreifuss, R.A. 1964: a conquista do Estado; ação política, poder e golpe de classe. Petrópolis, Vozes, 1981 .

25 Dreifuss, R.A. op. cit.

${ }^{26}$ Wahrlich, Beatriz M. de Souza. op. cit.

27. Pereira, L.C.B. Empresários e administradores no Brasil. São Paulo, Brasiliense, 1974.

28 Lopes, J.R.B. Sociedade industrial no Brasil. Sâo Paulo, Difusão Européia do Livro, 1964; Garcia Coutinho, F. Modernizaçáo e Reforma administrativa no Brasil: uma interpretaçāo dos impasses e um projeto alternativo. In: Modernizaçio administrativa. Brastlia, Ipea, 1978. p. 7-107; Motta, P.R. Variáveis que condicionam o comportamento da adminjstração pública brasileira. Revista de Administração Pública, 11(4):33-40, 1977.

${ }^{29}$ Hickson, D.J. \& McMillan, C. op. cit.

${ }^{30}$ Udy, S.H. op. cit.; Hall, H.R. op. cit.; Parsons, T. The Structure of social action. Chicago, Free Press, 1937.

31 Brossard, M. \& Marurice, M. Is there a universal model of organization structure? internacional studies of management \& organization, 6(3):11-45, 1976 .

32 Bertero, C.O. O contexto cultural das organizaçбes. Estudos e Pesquisas Cebrae, 1 :55-89, 1980.

${ }^{33}$ Vianna, O. Instituiçôes politicas brasileiras. Sâo Paulo, josé Olympio, 1949.

${ }^{34}$ Lopes, J.R.B. op. cit.

${ }^{35}$ Da Cunha, M.W.V. O sistema administrativo brasileiro, 1930 . 1950. Rio de Janeiro, Instituto Nacional de Estudos Pedagógicos. 1963.

${ }^{36}$ Da Matta, R. Carnavais, malandros e herbis. Rio de Janeiro, Zahar, 1978.

${ }^{37}$ Id. ibid. op. cit. p. 184.

${ }^{38}$ Hickson, D.J. \& McMillan, C. op. cit. p. 193.

${ }^{39}$ Pugh, D.S. \& Hickson, D.J., ed. Organizational structure in its context; the A ston Programme I. Weastmead, Saxon, 1976.

${ }^{40}$ McMillan, C.J.; Hickson, D.J.; Hinings, C.R. \& Schneck, R.E The structure of work crganizations across societies. A cademy of Management Journal, $16555-69,1973$.

41 Kuc, B.; Hickson, D.J. \& McMillan, C.J.. Centrally planned development: a comparison of Polish factories equivalents in Britain, Japan and Sweden. In: Hickson, D.J. \& McMillan, C., ed. op. cit. p. 79-91.

42 Naht, R..A methodological review of cross-curtural management research. Intermational Social Science Joumal, 20:35-62,
1968 . 
43 Ver detalhes sobre a coleta de dados em; Sá, R.C.R. Estrutura e contex to em organizaçōes brasileiras. Dissertaçáo de mestrado em administração. UFMG, 1982.

${ }^{44}$ Pugh, D.S. \& Hickson, D.J. op. cit.

45 Pugh, D.S. \& Hickson, D.J. op. cit.

${ }^{46}$ Hickson; D.J. \& McMillan, C. op. cit.

${ }^{47}$ Kuc, B.; Hickson, D.J. \& McMillan, C. op. cit.

${ }^{48}$ Id. Ibid.

${ }^{49}$ Shenoy, S. op. cit. p. 143.

${ }^{50}$ Kuc, B.; Hickson, D. J. \& McMillan, C. op. cit.

51 Child, J. \& Kieser, A. Organization and managerial roles in British and West German companies: an examination of the culture-free thesis. In: Hickson, D.J. \& McMillan, C., ed. op. cit. p. 51-73.

52 Das organizações de propriedade nacional, 14 entre 17 eram empresas familiares.

53 possível que estes fatores venham a explicar também a média baixa de centralização obtida em nossa amostra.

54 Hofstede, G. op. cit.

55 Bass, B.M.; Burger, P.C.; Doktor, R. \& Barret, G.V. A ssessment of managers; an international comparison. New York, The Free Press, 1979.

56 Beltrão, H. Programa Nacional de Desburocratização. Revista de Administração Pública. 15(3):93-119, jul./set. 1981.

${ }^{5} 7$ Hickson, D.J. \& McMillan, C. op. cit.p. 194.
58 Riggs, F.W. Bureaucrats and political development: a paradoxical view. In: LaPalombara, J., ed. Bureaucracy and political development. Princeton, N.J., Princeton University Press, 1963. p. $120-67$.

${ }^{59}$ Adler, Nancy. Epistemological foundations of a symposium process: a framework for understanding culturally diverse organizations. International Studies of Management and Organization, 12(4):3-22, 1983.

${ }^{60}$ Roberts, K. On looking at an elephant: an evaluation of crosscultural research related to organizations. Psychological bulet tin, 74:327-50.

${ }^{61}$ Roberts, K. \& Boyacigiller, N.A. Cross-national research: the grasp of the blind men. In: Cummings, L.L. \& Staw, B.M., ed. Research in organization behavior. Greewich, Conn., JAI Press, 1983.

62 Bertero, C.O. op. cit

${ }^{63}$ Crozier, M. The bureaucratic phenomenon. London, Tavistock, 1964 .

${ }^{64}$ Beres, M.E. \& Portwood, J.D. Sociocultural influences on organizations: an analysis of recent research. In: England, G.W.; Negandhi, A.R. \& Wilpert, B. ed. The functioning of complex organizations. Cambridge, Mass., Oelgeschlager, Gun \& Hain, 1981. p. 303-36.

${ }^{65}$ Hickson, D.J. \& McMillan, C. op. cit.

${ }^{66}$ Child, J. \& Kieser, A. op. cit.

${ }^{67}$ Azumi, K. \& McMillan; C.J. Bureaucracy culture and contingency theories in organizational analysis. International Studies of Management and Organization, 5(1) 35-47, 1975.

${ }^{68}$ Kuc, B.; Hickson, D.J. \& McMillan, C. op. cit.

\section{Revista de Administração de Empresas}

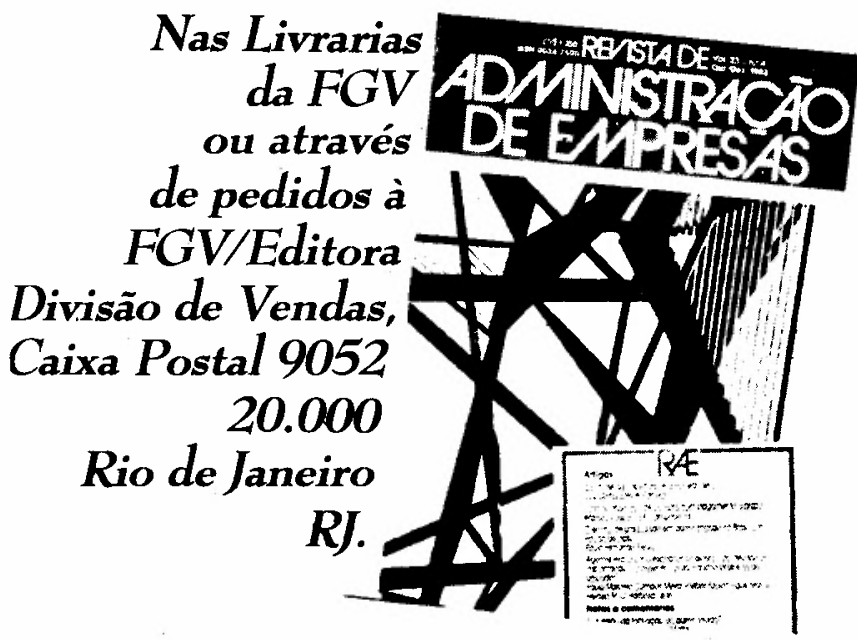

